\title{
Ortaokul Öğrencilerinin Farklı Temsil Biçimlerini Kullanarak Matematiksel Genelleme Yapma Becerileri ${ }^{1}$
}

\author{
Sibel Yeşildere-İmre ${ }^{2}$, Hatice Akkoç ${ }^{3}$ ve Burcu Nur Baştürk-Şahin ${ }^{4}$ \\ Makale geçmişi \\ Makale geliş tarihi: 23 Haziran 2016 \\ Yayına kabul tarihi: 30 Ocak 2017 \\ Çevrimiçi yayın tarihi: 31 Mart 2017
}

\begin{abstract}
Öz: Bu araştırmada farklı temsil biçimleriyle sunulan örüntüleri genellemede öğrencilerin düşünme şekillerini ve genelleme yapma türlerini incelemek amaçlanmaktadır. Öğrencilerin kullandıkları genelleme türlerinin kuramsal çerçeve bağlamında incelenmesi, cebirsel genelleme yapmaya engel olan düşünme şekillerinin belirlenmesi ve öğrencilerin farklı temsil biçimlerini genelleme yapma yönünde kullanma şekillerinin saptanması hedeflenmektedir. Bu bağlamda araştırmada örnek olay tarama modeli kullanılmıştır. Katılımcılar amaçlı örnekleme yöntemi ile seçilmiştir. Çalışma altıncı, yedinci ve sekizinci sınıfta okuyan 92 öğrenciyle gerçekleştirilmiştir. Elde edilen veriye betimsel ve içerik analizi uygulanmıştır. Veri analizi öğrencilerin cebirsel genelleme yerine aritmetik genelleme eğilimlerinin olduğunu göstermiştir. Öğrenciler şekil örüntülerini kullanarak cebirsel genelleme yapmada güçlük çekmişlerdir. Şekil örüntülerini sayı örüntüsüne dönüştürmüşler ve şekil örüntüsünden etkili şekilde yararlanamamışlardır.
\end{abstract}

Anahtar Kelimeler: Genelleme, cebirsel genelleme, temsiller

DOI: $10.16949 /$ turkbilmat.303220

\begin{abstract}
The purpose of this research is to examine the forms of thinking and generalization types of students during the generalization of the patterns presented with different representations. It is aimed to examine the generalizations used by the students through the theoretical framework, to determine the forms of thinking that prevent them from making algebraic generalization and to determine the use of different representations of the students. For this purpose, case survey research is used in the research. Participants were selected by purposeful sampling method. The study was conducted with 92 students studying in the sixth, seventh and eighth grades. Descriptive and content analysis were used to analyze the data. Data analysis has shown that students tended to have arithmetic generalizations rather than algebraic generalizations. Students have difficulties in making algebraic generalizations using pictorial patterns. They have transformed visual patterns into number patterns and have not been able to make effective use of pictorial patterns.
\end{abstract}

Keywords: Generalization, algebraic generalization, representations

See Extended Abstract

\section{Giriş}

Okul matematiği özünde cebiri barındırır (Otte, Mendonça, Gonzaga \& de-Barros, 2015). Cebir harflerin kullanıldığ 1 bir dil olmanın ötesinde bir düşünme biçimi olarak karşımıza çıkmakta ve değerler arasındaki ilişkileri analiz etmeyi, yapıyı görmeyi, doğrulamayı, problem çözmeyi, tahmin etmeyi ve genelleme yapmayı gerektiren cebirsel düşünmeyi içermektedir (Kieran, 1996). Cebirsel düşünmenin gelişimini sağlama yönünde

\footnotetext{
${ }^{1} \mathrm{Bu}$ çalışma XI. Ulusal Fen Bilimleri ve Matematik Eğitimi Kongresi'nde sunulan bildirinin genişletilmiş halidir.

${ }^{2}$ Doç. Dr., Dokuz Eylül Üniversitesi, Buca Eğitim Fakültesi, Matematik Eğitimi ABD, Türkiye, sibel.yesildere@deu.edu.tr

${ }^{3}$ Doç. Dr., Marmara Üniversitesi, Atatürk Eğitim Fakültesi, Matematik Eğitimi ABD, Türkiye, hakkoc@marmara.edu.tr

${ }^{4}$ Arş. Gör., Uludağ Üniversitesi, Eğitim Bilimleri Enstitüsü, İlköğretim ABD, Türkiye, burcu.n.basturk@gmail.com
} 
yapılan araştırmalarda özellikle genelleme yapma ve örüntüler üzerinde durulduğu görülmektedir (ör., Ferrara \& Sinclair, 2016; Moss \& Beatty, 2010; Rivera, 2011). Bunun temel nedeni öğrencilerin örüntüleri anlamlandırma ve genelleme yapma becerileri arasında ilişki bulunması (Warren, 2000), daha açık bir ifadeyle örüntü aramanın genelleme yapmanın temel ve gerekli adımlarından biri olmasıdır (Jones, 1993). Örüntülerin genelleme yapmayla olan yakın ilişkisini Wilkie (2016) şöyle açıklamaktadır: "genelleme yapmanın önemli bir yönü değişkenler arasındaki ilişkileri fark etme ve fonksiyonel bir kural olarak ifade etme becerisidir. Bu ilişkileri anlama ve sembolize etme becerisini geliştirmede izlenebilecek yollardan biri örüntülerin genellenmesidir (s.335).”

Genelleme yapma sadece cebirsel düşünmenin değil, matematiksel bilginin inşasında da önemli yere sahip bir düşünsel süreçtir. $\mathrm{Bu}$ yönüyle genelleme olgusu matematik eğitimi araştırmacıları tarafından çeşitli boyutlarıyla ele alınmış (ör., Davydov, 1990; Dörfler, 1991; Krutetskii, 1976; Rubinshtein, 1994; Venenciano \& Heck, 2016) ve öğrenme ve öğretmenin temel bileşenlerinden biri olarak yorumlanmıştır (Lannin, Ellis, Elliott \& Zbiek, 2011). Krutetskii (1976) genellemenin iki yönünü tanımlamıştır. İlk yönü kişinin genellemeyi belirli durumlardan şekillendirme becerisidir: özelden geneli görme. İkinci yön ise kişinin özel ve somut olan durumlardan geneli görme becerisidir. Bu ikinci yön kişinin özel bir durumu, genellemenin bir örneği olarak sınıflandırması diğer bir deyişle genelin içindeki özeli görmesidir. Bu açıklamayı sadeleştiren Mason (1996) genellemeyi ayrıntıları kullanarak geneli görme ve genelin içindeki ayrıntıları görme olarak ifade etmektedir. Kaput (1999) genellemeyi açıklarken seçilen örneklerin ötesinde muhakeme yapmanın gerekliliğine işaret ederken Harel ve Tall (1991) genelleme sürecinde verilen bir argümanı daha geniş bağlamda uygulanmasına vurgu yapmıştır.

Dörfler (1991) genelleme genel ve kişi arasında karşıllklı ilişkinin belirlenmesidir diyen Davydov'a (1990) kıyasla genelleme sürecini daha ayrıntılı olarak ele almış ve daha genel bir duruma rehberlik eden sosyal-bilişsel bir süreç olarak tanımlamıştır. Genellemeyi hem başlı başına bir kavram hem de bir düşünme ve iletişim yolu olarak açıklayan araştırmacı genellemeyi; "deneysel genelleme" ve "teorik genelleme" olarak ikiye ayırmıştır. Deneysel genelleme bir kavrama ait ortak özelliklerin fark edilmesine dayanmaktadır. Genelleme yapabilmek için gerekli olan özellikleri belirleme bağlamında yaşanabilecek sıkıntılar nedeniyle Dörfler bu genelleme türünün problemli olduğuna işaret etmiş ve bu görüşe karşıt bir genelleme türü olarak teorik genellemeyi ortaya koymuştur. Teorik genelleme, genelleme yapılacak matematiksel durumdaki gerekli olan ve değişken nitelikte olmayan özellikleri soyutlama yoluyla gerçekleşmektedir. Benzer şekilde Venenciano ve Heck (2016) genellemeyi geniş kapsamda şu şekilde ele almıştır:

Genelleme bir grup nesnenin arasındaki ortak ya da birleştirici özelliği araştırma süreci olarak düşünülebilir. Nesnelere ait özellikler arasında bazıları yüzeysel düzeyde olsa da genelleme yapma becerisi, çocukların anahtar niteliğindeki değişmezin farkına varmasını sağlar. Değişmez özelliğin üzerinde durmak çocukların diğer nesnelerin özelliklerini ayırt etmesini ve aynı gruba ait olup 
olmadıklarına karar vermelerini sağlar. Genelleme yapma öğrencilerin sistematik düşünmelerini ve kuralları somut durumlara uygulamalarını sağlar (s.23).

Genelleme yapma üzerine getirilen açıklamaların yanı sıra genellemeyi takip edilebilir ve gözlemlenebilir bir süreç olarak inceleme isteği, kuramsal çerçevelerin oluşmasına neden olmuştur (ör., Radford, 2008; Rivera, 2011). Bir sonraki alt bölümde genelleme yapma sürecini operasyonel olarak takip edebilmeyi sağlaması ve genelleme türlerini belirlemesi nedeniyle bu araştırmada kuramsal çerçeve olarak benimsenen "cebirsel örüntü genellemesinin inşası" (Radford, 2008) açıklanmaktadır.

\subsection{Kuramsal Çerçeve: Cebirsel Örüntü Genellemesinin İnşası}

Cebirsel örüntü genellemesi (architecture of algebraic pattern generalization) kuramsal çerçevesi Radford (2008) tarafından geliştirmiştir. Bu çerçeveye göre cebirsel örüntülerin genellenmesi süreci;

i. Sayı örüntüsündeki ortak özelliği fark etme,

ii. Fark edilen ortak özelliğin sayı örüntüsündeki diğer terimlerinde olup olmadığını inceleme,

iii. Örüntünün herhangi bir terimini direkt olarak bulmak için cebirsel bir kural oluşturma adımlarından oluşmaktadır. Cebirsel örüntü genellemesinin inşası adlı bu genelleme süreci Şekil 1'de görülmektedir.
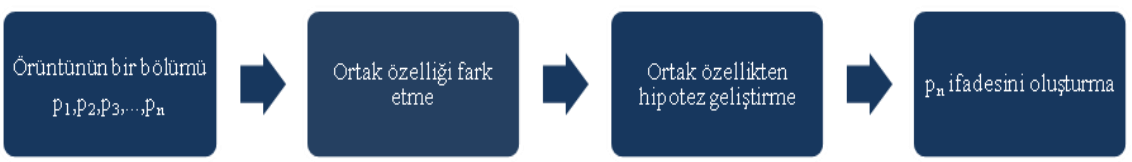

Ayırt etme

Transfer etme

Ortak özellikten $\mathrm{p}_{\mathrm{n}}$ oluşturma

Şekil 1. Cebirsel Örüntü Genellemesinin İnşası (Radford, 2008, s.85)

Aritmetik genelleme ise sayı örüntüsünün bütünü yerine belirli bir bölümüne odaklandığından elde edilen genelleme herhangi bir terimi bulmaya yönelik değildir ve cebirsel bir yapısı yoktur. Aritmetik genelleme süreci;

i. Sayı örüntüsündeki ortak özelliği fark etme,

ii. Fark edilen ortak özelliğin sayı örüntüsündeki diğer terimlerinde olup olmadığını inceleme,

şeklindedir. Aritmetik genelleme süreci Şekil 2'deki gibi gösterilebilir. 

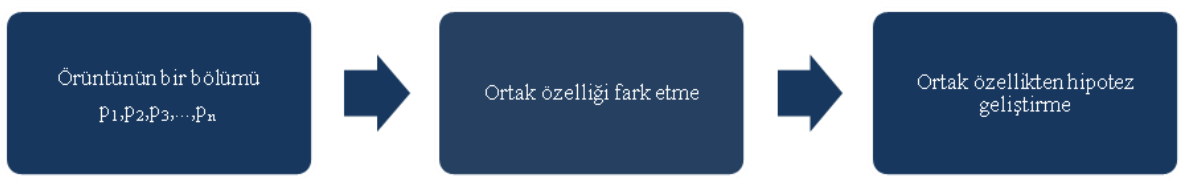

Ayırt etme

Transfer etme

Şekil 2. Aritmetik Genelleme Süreci (Radford, 2008)

Şekil 2'den görüldüğü gibi aritmetik genelleme sürecinde, cebirsel genellemenin inşasında yer alan son adım bulunmamaktadır. Terimler arası ilişkinin sayılarla belirtilmesi, ardışık terimin bulunması aritmetik genellemeye örnek olarak verilebilir.

Radford (2008) olgunlaşmamış tümevarımı; genellemeden bir kurala ulaşmak yerine kuralın denenmesi ile genellemeye ulaşılması olarak ifade eder. $\mathrm{Bu}$ yönüyle olgunlaşmamış tümevarım bir genelleme olarak kabul edilmez. Olgunlaşmamış tümevarım süreci Şekil 3'te görülmektedir.
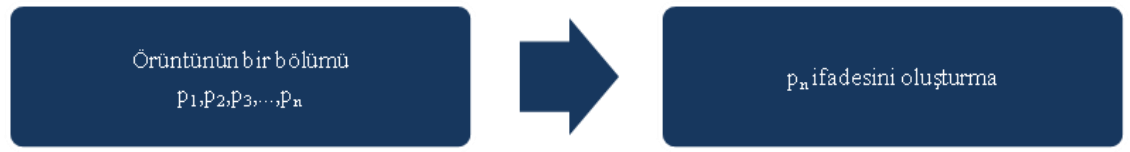

Ayırt etme

Şekil 3. Olgunlaşmamış Tümevarım Süreci (Radford, 2008, s. 86)

Şekil 3'te görüldüğü gibi olgunlaşmamış tümevarım süreci, cebirsel genelleme sürecinin ilk ve son adımlarına sahiptir. Sayı örüntüsünün terimleri arasındaki ilişkiyi incelemeden, deneme-yanılma yoluyla bir sayı örüntüsünün genel teriminin bulunması olgunlaşmamış tümevarım sürecine örnek olarak verilebilir.

Kuramsal çerçevede yer alan süreçleri örnek bir sayı örüntüsü üzerinden farklı temsil

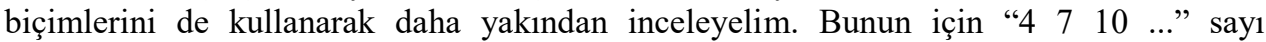
örüntüsünü ele alalım. Terimler arasındaki ortaklık, sayıların kendi özellikleri ve birbirleri arasındaki ilişkiyi dikkate alarak oluşturulmadığında ve buna dayalı olarak hipotez üretmeden cebirsel olarak ifade edildiğinde olgunlaşmamış tümevarım gerçekleşmektedir. Öğrencinin bu örüntünün kuralını hiçbir düşünsel sürece dayanmadan örneğin $4 \mathrm{n}$ olarak ifade etmesi, sonra doğruluğunu denemesi, sağlamadığını görünce yeni bir cebirsel ifade denemesi olgunlaşmamış tümevarıma örnek olarak verilebilir.

Verilen say1 örüntüsünün tablo olarak temsili Tablo 1'de verilmektedir. Öğrencinin terim sütununa bakarak sözel olarak terimlerin üçer üçer arttığını belirtmesi ya da terim ile terim sırası arasındaki ilişkiyi Tablo 1'de olduğu gibi nümerik olarak yazması aritmetik genellemeye örnektir. Bununla birlikte aritmetik genelleme yapan öğrenciler Tablo 1'in 
son satırında olduğu gibi notasyon kullanarak hipotezlerini yazamazlar. Notasyon kullanarak hipotezlerini yazabilen öğrenciler, cebirsel genelleme yapmış olurlar.

Tablo 1. 4710 örüntüsünün tablo ile gösterimi

\begin{tabular}{cccc}
\hline Terim Sırası & Terim & \multicolumn{2}{c}{ Terim strası ve Terim arasındaki ilişki } \\
\hline 1 & 4 & $(3.1)+1$ & $(1+1)+2.1$ \\
\hline 2 & 7 & $(3.2)+1$ & $(2+1)+2.2$ \\
\hline 3 & 10 & $(3.3)+1$ & $(3+1)+2.3$ \\
\hline$\ldots$ & $\ldots$ & $\ldots$ & $\ldots$ \\
\hline$n$ & $\ldots$ & $(3 . n)+1$ & $(n+1)+2 . n$ \\
\hline
\end{tabular}

Verilen sayı örüntüsünün şekil olarak temsili Şekil 4'teki gibi olabilir.
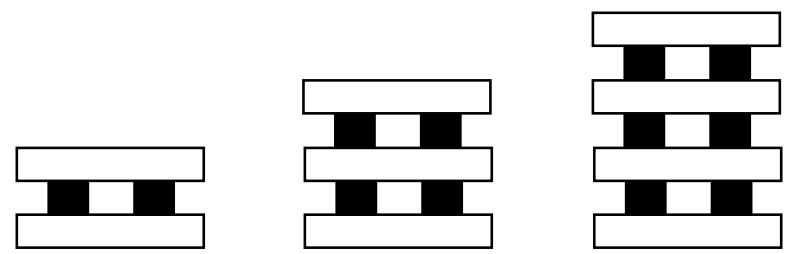

Şekil 4. Şekil örüntüsü (Frobisher \& Threlfall, 1999)

Bu şekil örüntüsü Şekil 5.a ve Şekil 5.b'deki gibi kullanılarak şekiller arasındaki ortaklığın yakalanması ve cebirsel olarak ifade etmeyi sağlayacak bir hipotezin oluşturulması cebirsel genelleme yapmayı desteklemektedir.
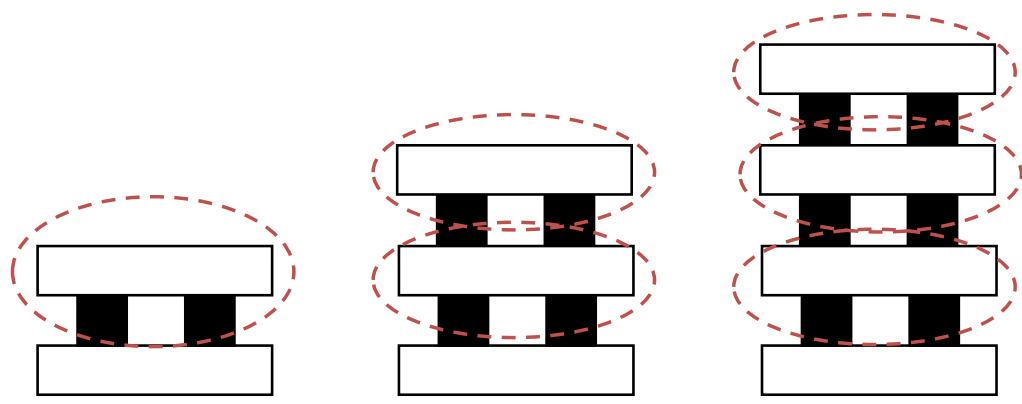

$3 . \mathrm{n}+1$

Şekil 5.a. Cebirsel genellemeyi sağlayacak şekilde şekil örüntüsünün kullanımı-1 

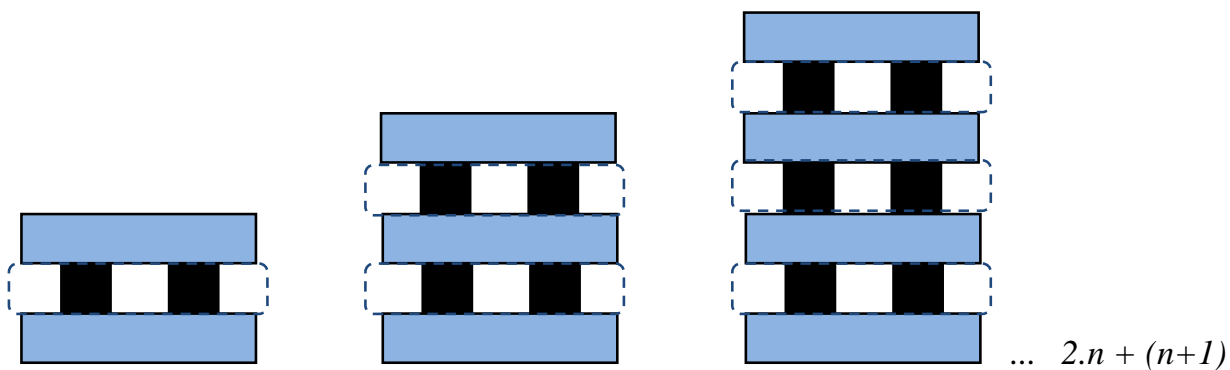

Şekil 5.b. Cebirsel genellemeyi sağlayacak şekilde şekil örüntüsünün kullanımı-2

Şekil 5.a şekil örüntüsündeki şekillerin her birinde bir yatay iki dikey durumda olan üçlü yapının olduğunun fark edilmesine ve bu durum dikkate alınarak ortak özelliğin belirlenmesine örnek bir yaklaşımdır. İlk şekilde üçlü yapıdan bir tane, ikinci şekilde iki tane, üçüncü şekilde üç tane olduğu belirlenmiştir. Bu durumda n. şekilde de $3 n$ tane üçlü yapı bulunacaktır. $\mathrm{Bu}$ yapının yanı sıra her şekilde bir adet yatay sütun bulunduğundan belirlenen bu ortak özelliklerden $\mathrm{p}_{n}$ ifadesi 3.n+1 şeklinde oluşturulabilir. Şekil 5.b'de ise ortak özellik, her şekilde bulunan ikili düşey yapıdır. Her şekilde şekil sayısının iki katı kadar sayıda ikili sütun bulunmaktadır. Ayrıca her şekilde, şekil sayısının bir fazlası kadar yatay şekil bulunmaktadır. Bu ortak özellikten hareketle hipotez "şekil sayısının iki katı kadar dikey, bir fazlası kadar dikey sütun vardır" şeklinde yazılarak $\mathrm{p}_{n}$ ifadesi $2 . n+(n+1)$ şeklinde oluşturulabilir.

Yukarıda örneklendirildiği gibi bir sayı örüntüsüne ilişkin genellemeye belli düşünsel süreçlerden geçilerek ulaşma ile deneme yanılma üzerinden ulaşma arasında fark vardır. Genelleme yapma becerisi açıklanan kuramsal çerçevede olduğu gibi ayırt etme, transfer etme ve ortak özellikten $\mathrm{p}_{n}{ }^{\prime} \mathrm{i}$ elde etme süreçlerinden geçerek olgunlaşmaktadır. $\mathrm{Bu}$ süreçler kendini sayı örüntülerinde açıkça göstermediğinde, tablo veya şekil temsillerinden yararlanılması genelleme yapmada örüntüdeki ortak özelliği fark etmeyi de kolaylaştırmaktadır.

\section{2. İlgili Yayınlar ve Araştırmalar}

Örüntüler ve genelleme üzerine literatürde oldukça çok sayıda araştırma bulunmaktadır. $\mathrm{Bu}$ araştırmaların büyük bir kısmı genellemede kullanılan stratejileri belirleme üzerinedir. Yakut-Çakır ve Akyüz (2015) 425 dokuzuncu sınıf öğrencisinin lineer şekil örüntülerini genellemeye yönelik problemleri çözerken kullandıkları genelleme stratejilerini incelemişlerdir. Araştırma verilerine göre öğrencilerin yakın terimi bulmada uzak terimi bulmaya göre daha başarılı olmuşlar, yakın ve uzak terimleri ya art arda sayıları yazarak ya da terimler arasındaki farkı bulup bir önceki terime ekleyerek elde etmeye çalışmışlardır. Benzer konuyu ortaokul öğrencileriyle gerçekleştiren Özdemir, Dikici ve Kültür (2015) yedinci sınıf öğrencilerinin örüntüleri genelleme süreçlerini incelemişlerdir. Araştırma sonuçlarına göre öğrenciler verilen şekilleri veya şekillerin 
yapılarını dikkate almamışlar, örüntülerin kurallarını bulmak için sadece sayısal ilişkilere odaklanmışlardır. Örüntülerin kuralını bulmada en yüksek başarı tekrarlı, en düşük başarı ise artarak genişleyen örüntü sorularında görülmüştür. Beşinci sınıf düzeyinde örüntüleri genellemede kullanılan öğrenci stratejilerini araştıran Tanışlı ve Özdaş (2009), araştırma sonucunda, sabit ve artarak değişen şekil örüntülerin genellenmesinde görsel ve cebirsel yaklaşımın benimsendiği, görsel yaklaşımın ve örüntülerin yapısal özelliklerinin de genelleme yapabilmeyi kolaylaştırdığını tespit etmişlerdir. Yakın genellemelerde bir önceki terimin kullanılmasını gerektiren yinelemeli, uzak genellemelerde ise fonksiyonel bir ilişkinin kullanılmasını gerektiren belirgin stratejilerin kullanıldığını görmüşlerdir. Şekil örüntüsü oluştururken kullanılan stratejileri ve oluşturulan şekil örüntü tiplerini inceleyen Kılıç (2016) ise 474 ortaokul öğrencisi ile gerçekleştirdiği araştırmasında öğrencilerin kullandıkları stratejilerin hem görsel, hem de görsel olmayan yapıya sahip stratejiler olduğu bulgusuna ulaşmıştır. Radford (2010) strateji kullanımının dışına çıkarak ikinci sınıf öğrencilerinin erişebilecekleri cebirsel düşünme türlerini öğrenciler henüz notasyon kullanımı ile tanışmadan önce şekil örüntülerini kullanarak incelemiştir. Araştırmacı çocukların örüntünün bilinmeyen adımını bulma için gerekli hesaplamayı tanımlayarak değişkeni anlaşılır hale getirdikleri sonucuna ulaşmıştır. Farklı genelleme türleri ve aşamaları üzerine çalışan araştırmacılardan olan Carraher, Martinez ve Schliemann, (2008) öğrencilerin somut düzeyden başlayarak genellemenin değişik düzeylerine ilerlediklerini ve sembolik genellemeye ulaştıklarını bulmuşlardır.

Örüntü genellemeyi konu edinen araştırmaların bazıları da öğretmen adaylarıyla gerçekleştirilmiştir. Tanışlı ve Yavuzsoy-Köse (2011) on altı sınıf öğretmeni adayının lineer şekil örüntülerini genelleme stratejilerini araştırmışlardır. Araştırma sonucunda, kimi öğretmen adaylarının lineer şekil örüntüsünü yakın/uzak bir adıma devam ettirmede ve örüntünün kuralını belirlemede şekil örüntüsünün sayı örüntüsüne dönüştürüldüğü sayısal yaklaşımı benimsedikleri belirlenmiştir. Araştırmacılar örüntüleri genellerken öğretmen adaylarının ağırlıklı olarak sadece terimler arası ilişkinin araştırıldığg yinelemeli stratejileri kullandıklarını rapor etmişlerdir. Yılmaz ve Argün (2013) beş öğretmen adayının katılımcı olduğu araştırmalarında katılımcıların genelleme yapabilecekleri uygun ortamlar içinde hangi görselleştirmeleri nasıl kullandıklarını ve ne tür görsel imajlara sahip olduklarını araştırmışlardır. Sonuç olarak yapılan görselleştirmelerin, katılımcıların genelleme sürecini tamamlamalarında önemli bir yere sahip olduğunu belirtmişlerdir.

Literatürde yer alan araştırmalara ek olarak bu araştırmada farklı temsil biçimleriyle sunulan örüntüleri genellemede öğrencilerin düşünme şekillerini ve genelleme yapma türlerini incelemek amaçlanmaktadır. Bu bağlamda, öğrencilerin farklı temsil biçimleriyle sunulan örüntüleri genelleme türlerinin kuramsal çerçeve bağlamında incelenmesi, farklı genelleme türünün ortaya çıkmasına neden olan düşünme şekillerinin ortaya çıkarılarak cebirsel genelleme yapmaya engel olan düşünme şekillerinin belirlenmesi ve öğrencilerin farklı temsil biçimlerini genelleme yapma yönünde kullanma şekillerinin saptanması istenmektedir. Farklı temsil biçimlerinin cebirsel genelleme yapmaya katkısını belirleyerek örüntülerin genellenmesinde temsillerin etkili şekilde kullanılmasına dikkat çekmesi bağlamında araştırmanın, yukarıda kısaca rapor edilen literatüre katkı sağlayacağı 
düşünülmektedir. $\mathrm{Bu}$ amaç doğrultusunda araştırmanın alt problemleri şöyle oluşturulmuştur:

a. Ortaokul öğrencileri farklı temsil biçimleriyle sunulan örüntüleri genellemede hangi genelleme türünü kullanmaktadır?

b. Ortaokul öğrencilerinin cebirsel genelleme yapmaya engel olan düşünme şekilleri nelerdir?

c. Ortaokul öğrencileri genelleme yaparken farklı temsil biçimlerini nasıl kullanmaktadır?

\section{Yöntem}

Araştırmada tarama modeli kullanılmıştır. Tarama modeli var olan durumu araştırıp açıklamayı amaçlamakta, konuyla ilişkili verilerin gözden geçirilmesi mantığına dayanmaktadır (Yıldırım ve Şimşek, 2013). Tarama modellerinden örnek olay tarama modeli benimsenmiştir. Örnek olay tarama modeli, belirli bir olguya ilişkin ayrıntılı betimleme yapmak amacıyla kullanılmaktadır (Yıldırım ve Şimşek, 2013). Ortaokul öğrencilerinin farklı temsil biçimleriyle sunulan örüntülere ilişkin cebirsel genelleme yapma sürecinde izledikleri yolları belirleme amaçlandığından bu model tercih edilmiştir.

Örnek olay tarama modellerinde incelenen olguya ilişkin bulguların ve açıklamaların gücünü artırma amacıyla sınırlı bir örneklem ve daha dar tanımlanmış bir olgu üzerinde derinlikli çalışılmaktadır. Bu bağlamda araştırmanın katılımcıları, amaçlı örnekleme yöntemlerinden tipik durum ile seçilmiştir. İzmir merkez okullarında öğrenim gören ve katılmaya gönüllü olan toplam 92 tane altıncı, yedinci ve sekizinci sınıf öğrencisiyle gerçekleştirilmiştir. Katılımcılar orta sosyoekonomik düzeye sahip on farklı okuldan seçilmiştir.

Veri toplama aracında sayı örüntülerini genellemeye ilişkin üç tip soru bulunmaktadır. Farklı temsil biçimlerinde öğrencilerin benimsedikleri yaklaşımları belirlemek için her soru tipinden ikişer tane soruya yer verilmiştir. İlk soru tipi, nümerik olarak sunulan örüntülerin genellenmesine yöneliktir. Bu sorulardan ilki kuralı tek işlem içerecek $(n)$, diğeri iki işlem içerecek $(5 n+3)$ şekilde hazırlanmıştır. İkinci soru tipinde şekil örüntüsü verilerek kurallarının bulunması istenmiştir. Şekil örüntüleri, sadece şekil kullanılarak genel terimin bulunmasını sağlayacak şekilde hazırlanmıştır. Bu örüntüler Şekil 6'da verilmektedir. 

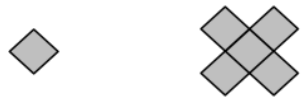

1. şekil

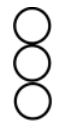

1. şekil
2. şekil

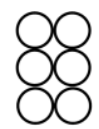

2. şekil

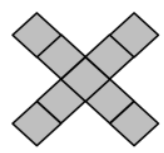

3. şekil

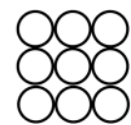

3. şekil

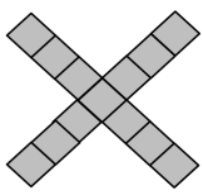

4. Şekil

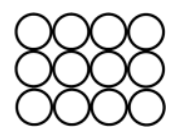

4. şekil

Şekil 6. Şekil temsili ile sunulan örüntü soruları

Son soru tipi aralıklı olarak bazı değerleri verilmeyen ve tablo olarak sunulan sayı örüntüleridir. Bu sorular aşağıda verilmektedir.

\begin{tabular}{|c|c|}
\hline Sira no & Terim \\
\hline 1 & 4 \\
\hline 2 & 5 \\
\hline 3 & 6 \\
\hline$\ldots$ & $\ldots$ \\
\hline 14 & $?$ \\
\hline$\ldots$ & $\ldots$ \\
\hline 70 & $?$ \\
\hline$\ldots$ & $\ldots$ \\
\hline$\ldots$ & $\ldots$ \\
\hline$\ldots$ & $\ldots$ \\
\hline $\mathrm{n}$ & $?$ \\
\hline
\end{tabular}

\begin{tabular}{|c|c|}
\hline Sira no & Terim \\
\hline 1 & 2 \\
\hline$\ldots$ & $\ldots$ \\
\hline 6 & 17 \\
\hline$\ldots$ & $\ldots$ \\
\hline 18 & 53 \\
\hline$\ldots$ & $\ldots$ \\
\hline 30 & 89 \\
\hline$\ldots$ & $\ldots$ \\
\hline $2^{78}$ & $?$ \\
\hline$\ldots$ & $\ldots$ \\
\hline $\mathrm{n}$ & $?$ \\
\hline
\end{tabular}

Veri toplama aracında her bir soru için sadece cevapların değil aynı zamanda düşünme şekillerinin de yazılması özellikle istenmiştir. Uygulama sürecinde de bu yönde açıklamalar hem araştırmacılar hem de ders öğretmeni tarafından yapılmıştır. $\mathrm{Bu}$ bağlamda hazırlanan soruların öğrencilerin genelleme türlerini, cebirsel genelleme yapmaya engel olan düşünme şekillerini ve farklı temsil biçimlerini kullanma şekillerini analiz etmeye imkân tanıdığı düşünülmektedir. Hazırlanan altı soruluk veri toplama aracı beş ortaokul yedinci sınıf öğrencisine uygulanarak ve iki matematik eğitimcisinin uzman görüşüne sunularak son haline getirilmiştir.

Elde edilen veri içerik analizi ve betimsel yöntemleri ile analiz edilmiştir. Betimsel analiz, doğrudan alıntılara yer verilen ve elde edilen verilerin daha önceden belirlenen temalara göre özetlenip yorumlanmasını gerektiren bir yaklaşımdır (Yıldırım ve 
Şimşek, 2013). Araştırmada öğrencilerin kullandıkları genelleme türleri Radford (2008) tarafindan tanımlanan kuramsal çerçeve ile belirlenen temalar doğrultusunda yorumlandığından betimsel analiz yapılmıştır. Diğer yandan, öğrencilerin yanılgılarının ve kullandıkları farklı temsil biçimlerinin ortaya çıkarılmasında içerik analizi kullanılmıştır. Nitel verinin sayısallaştırılması güvenirliği arttırır (Yıldırım ve Şimşek, 2013). Bu bağlamda nitel veri frekans hesabı yapılarak sayısallaştırılmış ve analiz gerçekleştirilmiştir. Bunun için Yıldırım ve Şimşek'in (2013) yaklaşımı benimsenmiştir. Öncelikle analiz birimi saptanmış ve kategoriler tanımlanmıştır. Daha sonra kodlama örnek bir veri seti üzerinde denenmiş ve kodlama sonuçları ile önceden saptanmış olan kategoriler tekrar gözden geçirilmiştir. Son olarak verinin tümü kodlanmış ve frekanslar hesaplanmıştır.

\section{Bulgular}

Öğrencilerin cevap kâğıtlarında sorulara verdikleri cevaplardan elde edilen veriler analiz edildiğinde oluşturulan başlıklar ve alt başlıklar Tablo 3'de görülmektedir. Başlıklar ve alt başlıklar; araştırmanın alt problemleri, kuramsal çerçevede yer verilen kavramlar ve öğrencilerin cevaplarından yola çıkılarak oluşturulmuştur.

Tablo 3.Öğrencilerin örüntüleri genellemelerinde ortaya çıkan kategoriler ve alt kategoriler

\begin{tabular}{|c|c|}
\hline Başlıklar & Alt Başlıklar \\
\hline \multirow{3}{*}{ Genelleme Türleri } & Aritmetik genelleme \\
\hline & Cebirsel genelleme \\
\hline & Olgunlaşmamış tümevarım \\
\hline \multirow{3}{*}{$\begin{array}{l}\text { Öğrencilerin Düşünme } \\
\text { Şekilleri }\end{array}$} & Artış miktarını örüntünün genel terimi olarak ifade etme \\
\hline & Kuralı sözel ifadelerle sınırlama \\
\hline & Takip eden terimi örüntünün genel terimi kabul etme \\
\hline \multirow{3}{*}{ Çoklu Temsil Kullanımları } & Şekil örüntüsünü sayı örüntüsüne dönüştürme \\
\hline & Say1 örüntüsünü tabloya dönüştürme \\
\hline & Say1 örüntüsünü şekil örüntüsüne dönüştürme \\
\hline
\end{tabular}

Her bir kategoriye ilişkin frekansları belirten tablolar ve doğrudan alıntılar, genelleme türleri, ögrencilerin düşünme şekilleri ve temsil kullanımları başlıklı alt bölümlerde ele alınmaktadır.

\subsection{Genelleme Türleri}

$\mathrm{Bu}$ bölümde araştırmanın ilk alt problemi olan "ortaokul öğrencileri farklı temsil biçimleriyle sunulan örüntüleri genellemede hangi genelleme türünü kullanmaktadır?" sorusu ele alınmaktadır. Genelleme türleri kategorisine bakıldığında Radford'un (2008) kuramsal çerçevesinin aritmetik genelleme, cebirsel genelleme ve olgunlaşmamış tümevarım olarak üç alt kategori barındırdığı görülmektedir. Öğrencilere yöneltilen 
sorular tablodan ve modelden yararlanmayı gerektiren ve direkt sayıları içeren örüntülere ilişkindir. Öğrencilerden beklenen farklı temsil biçimlerinde sunulan bu örüntüler arasındaki ilişkileri doğru kullanmaları ve cebirsel genelleme yaparak sayı örüntülerinin genel terimlerini bulmalarıdır. Öğrencilerin bu üç alt kategori bağlamında örnek olabilecek cevapları Tablo 4 'te sunulmaktadır.

Tablo 4. Genelleme türlerine göre öğrencilerin verdiği cevap örnekleri

\begin{tabular}{lcl}
\hline $\begin{array}{l}\text { Genelleme } \\
\text { Türleri }\end{array}$ & Öğrenci & Örnek Cevap \\
\hline $\begin{array}{l}\text { Aritmetik } \\
\text { Genelleme }\end{array}$ & $\ddot{O ̈}_{65}$ & $\begin{array}{l}\text { "...bu sayı örüntüsünde sayılar beşer beşer artmıştır." } \\
\text { (Soru 1.b) }\end{array}$ \\
\hline
\end{tabular}

Cebirsel

Genelleme

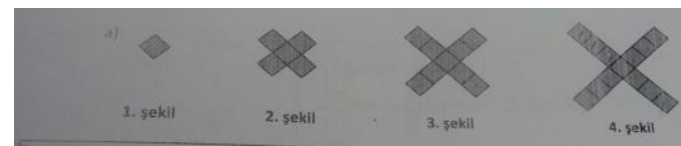

(Soru 2.a)

Olgunlaşmamış

Tümevarım

$\ddot{O}_{18}$
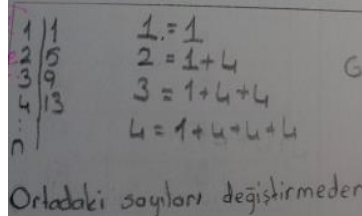

(Soru 2.a)

Ö$_{65}$ 'in örüntülerin biri için yapmış olduğu yorum, terim ile sırası arasındaki ilişki yerine ardışık terimler arasındaki ilişkiye odaklandığından aritmetik genelleme yaptığını gösterir niteliktedir. $\ddot{O}_{8}$ şekil örüntüsündeki modeli doğru şekilde yorumlamış ve cebirsel bir genellemede bulunmuştur. İşlemsel olarak yaptığı çözümün yanı sıra, sorunun altında yapmış olduğu açıklamada da öğrencinin ortada yer alan kareyi sabit tutarak kenarındaki kareleri adım sayısının bir eksiği kadar artırmayı açıklaması da cebirsel genelleme yaptığını gösterir niteliktedir. Ö̈'in çözümünün altında yapmış olduğu açıklama olgunlaşmamış tümevarımda bulunduğunu ortaya koyan bir açılama olmuştur. Denemeyanılma yöntemi öğrencinin herhangi bir genellemede bulunmaksızın sonucu ortaya koyduğu bir yöntem olduğundan bu soru kapsamında öğrencinin olgunlaşmamış tümevarım yaptığı söylenebilir. 
Öğrencilerin cevapları ile örneklendirilen genelleme türlerinin frekansları Tablo 5'te verilmektedir.

Tablo 5. Genelleme türlerinde ortaya çıkan alt kategoriler

\begin{tabular}{|c|c|c|c|c|c|c|c|c|}
\hline \multirow[t]{2}{*}{ Kategoriler } & \multirow[t]{2}{*}{ Alt Kategoriler } & \multicolumn{6}{|c|}{ Frekans } & \multirow[t]{2}{*}{ Toplam } \\
\hline & & $1 . \mathrm{a}$ & 1.b & $2 . \mathrm{a}$ & $2 . b$ & $3 . \mathrm{a}$ & $3 . b$ & \\
\hline \multirow{6}{*}{$\begin{array}{l}\text { Genelleme } \\
\text { Türleri }\end{array}$} & Aritmetik & & & & & & & \\
\hline & Genelleme & 58 & 64 & 56 & 58 & 18 & 0 & 254 \\
\hline & Cebirsel & & & & & & & \\
\hline & Genelleme & 28 & 18 & 15 & 19 & 53 & 12 & 145 \\
\hline & Olgunlaşmamış & & & & & & & \\
\hline & Tümevarım & 6 & 9 & 11 & 7 & 9 & 15 & 57 \\
\hline \multicolumn{2}{|c|}{ Soruyu Cevaplayan } & 92 & 91 & 82 & 84 & 80 & 27 & 456 \\
\hline
\end{tabular}

Öğrenciler tarafından toplam 456 tane genelleme yapılmıştır. Bunlardan 254'ü aritmetik genelleme, 145 'i cebirsel genelleme ve 57 'si olgunlaşmamış tümevarımdır. $\mathrm{Bu}$ sonuçlara göre tüm sorular genelinde $\% 55$ oranında aritmetik genelleme, $\% 31$ oranında cebirsel genelleme ve \%12 oranında olgunlaşmamış tümevarım yapıldığı söylenebilir.

Sorular özelinde veri ele alındığında örüntünün sayısal olarak sunulduğu birinci soruda 122 öğrencinin (\%67) aritmetik genelleme yaptığı tespit edilmiştir. Aritmetik genelleme yapan öğrenciler genel terim yerine verilmeyen ardışık terimi bulmuşlardır. $\mathrm{Bu}$ öğrencilerden biri olan $\ddot{O}_{1}$ 'in cevabı örnek olarak aşağıda verilmektedir:

"sayı örüntüsünde örüntü bir önceki sayının bir fazlası. Bu yüzden $4+1=5$ olduğu için bilinmeyen saylyı 5 buldum."

Birinci soruda öğrencilerin 46 tanesi (\%25) cebirsel genelleme yapmışlardır. $\mathrm{Bu}$ şekilde genelleme yapan öğrenciler terim sayısı ile terim arasındaki ilişkiyi araştırmışlardır. $\mathrm{Bu}$ öğrencilerden $\ddot{\mathrm{O}}_{3}$ sayısal ilişkiyi $1,2,3,4, \ldots$ örüntüsü üzerinden incelemiştir:

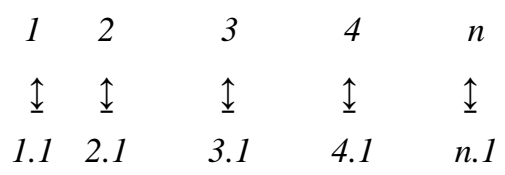

Genel terim n.1 olarak bulunur. 
Başka bir öğrenci, $\ddot{O}_{23}, 8,13,18,23, \ldots$ sayı örüntüsünü farklı bir forma dönüştürerek yazmıştır:

$\begin{array}{ccccc}5+3 & 10+3 & 15+3 & 20+3 & \ldots \\ (5.1)+3 & (5.2)+3 & (5.3)+3 & (5.4)+3 & (5 . n)+3 \\ 1 & 2 & 3 & 4 & n\end{array}$

Birinci soruda olgunlaşmamış tümevarım kullanan 15 öğrenci (\%15) vardır. Olgunlaşmamış tümevarım yapan öğrenciler rastgele bir genel terim yazmış ve doğru olup olmadığını deneme yanılma yoluyla incelemişlerdir.

Öğrencilere şekil örüntüsü verilerek genel terimi istenen ikinci soruda aritmetik genelleme yapan öğrenci sayısı 114'tür (\%69). Öğrencilerin aritmetik genelleme yaparken ardışık şekillerde bulunan nesne sayısını sayarak artış miktarını belirledikleri ve bir sonraki şekli oluşturdukları gözlemlenmiştir. Örneğin Ö$_{88}$ ikinci sorunun a seçeneğine "dörder dörder gider" b seçeneğine "ü̧̈er üçer gider" yanıtını vermiştir. Benzer şekilde $\ddot{O}_{64}$ "örrüntüde şekiller 4'er 4'er artmıs. 1'e 4 eklersek 5, 5'e 4 eklersek 9, 9'a 4 eklersek 13 olur. Bunu nereden anladım, şekilleri saydım ve buldum." şeklinde yanıtlamıştır. Bunun yanı sıra modeli inceleyerek ortak noktayı fark eden ancak cebirsel olarak yazamayan öğrenciler de bulunmaktadır. Ö$_{84}$ buna örnek olarak verilebilir. Kendisi ikinci sorudaki ilk şekil örüntüsünü inceleyerek "ortadaki (şekil) aynı, yandakiler (şekiller) 4'er 4'er artmış" cevabını vermiştir. Aynı sorunun ikinci seçeneğinde "yanlarına 3 (şekil) gelmiş hep" cevabını vermiştir. Ortak noktayı belirlemiş olsa da genel terimi ifade edememiştir.

İkinci soruda cebirsel genelleme yapan öğrenci sayısı 34'tür (\%20). Cebirsel genelleme yaparken öğrencilerin şekil örüntüsünü inceledikleri ve örüntüdeki ortaklığ 1 yakalayarak terim sayısı ile ilişkilendirdikleri görülmüştür. Ö ${ }_{6}^{\prime}$ 'nın cevabı cebirsel genelleme yapan öğrencilere örnek olarak verilebilir:

"Her sirada ortadakini sabit tuttum. Her sirada 4 tane artiyor.

$$
\begin{aligned}
& 1 \rightarrow 1 \\
& 2 \rightarrow 1+4 \\
& 3 \rightarrow 1+4+4 \\
& 4 \rightarrow 1+4+4+4 \\
& O \text { halde } 1+(n-1) .4 \text { genel terimdir. }
\end{aligned}
$$

İkinci soruda olgunlaşmamış tümevarım yapan 18 öğrenci (\%11) diğer sorularda olduğu gibi rastgele yazdıkları genel terime değerler vererek doğruluğunu incelemişlerdir.

Üçüncü soruda sayı örüntüsü tablo halinde sunulmuştur. İlk seçenekte 1., 2., 3., 14. ve 70. terimleri verilerek genel terim sorulmuştur. İkinci seçenekte ise ardışık olmayan terimler verilmiş ve genel terim istenmiştir. Üçüncü soru en az yanıt verilen sorudur. 
Özellikle sorunun b seçeneğini öğrencilerin \%5'i yanıtlamıştır. Bu soruda 18 öğrencinin (\%17) aritmetik genelleme yaptıkları belirlenmiştir. Aritmetik genelleme yapan ögrenciler tablonun sağ sütununda yer alan değerler arasında ilişki kurarak kuralı incelemişlerdir. $\mathrm{Bu}$ kullanıma örnek olarak $\ddot{O}_{65}$ 'in cevabı verilebilir: "bu sayı örüntüsünde sayılar üçer üçer artmıştır.". Aynı sorunun b seçeneğinde aritmetik genelleme yapan öğrenci bulunmamaktadır. Üçüncü soruda cebirsel genelleme yapan 65 öğrenci (\%61) bulunmaktadır. Cebirsel genelleme yapan öğrenciler, tablonun iki sütununda verilen sayılar arasında ilişki kurmaya çalışmışlardır. Bunlardan biri olan $\mathrm{O}_{1}$ a seçeneğine "sayı örüntüsünde terim sıra numarasının 3 fazlasıdır. Bu örüntüdeki kural n+3'tür” ve b seçeneğine "sayı örüntüsünde terim sira numarasının 3 katının 1 eksiğidir. Bu örüntüdeki kural n.3-1'dir." diyerek cebirsel genelleme yapmıştır. Benzer şekilde $\mathrm{O}_{70}$ " $\mathrm{n}+3$. Çünkü her terimde terim sayıs1+3 oluyor" yanıtını vermiştir. Üçüncü soruda 24 öğrenci (\%22) olgunlaşmamış tümevarım kullanmıştır.

Özetlenecek olursa öğrenciler özelikle sayı ve şekil olarak sunulan örüntülerde (1. ve 2. sorular) çoğunlukla aritmetik genelleme yapmışlardır. Cebirsel genelleme yapmanın en fazla olduğu temsil biçimi, tablo ile ilk üç terimi verilen örüntüye aittir. Bununla birlikte klasik bir tablo temsilinin sunulmadığı 3.b, öğrencilerin en az yanıtladığı soru olmuş ve yanıtlayanların çoğunluğu olgunlaşmamış tümevarım yoluyla genellemeye ulaşmaya çalışmışlardır. Öğrencilerin özellikle şekil örüntülerini önce sayı örüntüsüne dönüştürdükleri, daha sonra ardışık terimler arası ilişkiyi kullanarak genelleme yaptıkları görülmüştür. Genelleme türleri bağlamında öğrencilerin cebirsel genellemelere göre aritmetik genellemeler ve olgunlaşmamış tümevarımlar yapmayı daha fazla tercih ettikleri görülmesine karşın 3.a numaralı soruda cebirsel genellemenin daha fazla tercih edildiği görülmüştür.

\section{2. Öğrencilerin Düşünme Şekilleri}

$\mathrm{Bu}$ bölümde araştırmanın ikinci alt problemi olan "ortaokul öğrencilerinin cebirsel genelleme yapmaya engel olan düşünme şekilleri nelerdir?" sorusu ele alınmaktadır. Elde edilen öğrenci cevapları incelendiğinde düşüncelerinin öğrencilerin artış miktarını örüntünün genel terimi olarak ifade etme, genel terimi sözel ifadelerle sinırlama ve takip eden terimi genel terim kabul etme başlıkları altında toplandığı görülmektedir. Öğrencilerin artış miktarını genel terim olarak düşünmesine $\mathrm{O}_{14}{ }^{\prime}$ ün, örüntünün kuralını sözel ifadelerle sınırlayarak açıklamasına $\mathrm{O}_{63}$ 'ün ve takip eden terimi sayı örüntüsünün genel terimi olarak kabul etmesine Ö$_{36}$ 'nın verdiği yanıtlar örnek olarak Tablo 6'da sunulmaktadir. 
Tablo 6. Öğrencilerin düşünme şekillerine örnekler

\section{Öğrencilerin Düşünme Öğrenci Örnek Cevap}

Şekilleri

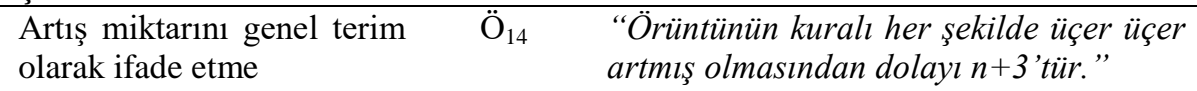

(Soru 2.b)

Örüntünün kuralını sözel $\quad$ Ö$_{63} \quad$ "Bu şekillerde her üç tanesinin yanına üç

ifadelerle sinırlama tane daha eklendiğini gördüm. Genel terim budur."

(Soru 2.b)

Takip eden terimi sayı $\quad$ Ö$_{36} \quad$ "Çünkü beşer beşer artmıştır. Buna göre örüntüsünün genel terimi genel terim yirmi üçten sonra gelen yirmi olarak kabul etme sekizdir."

(Soru 1.b)

Örneklendirilen bu düşünme şekillerine ilişkin frekanslar, Tablo 7'de verilmektedir.

Tablo 7. Öğrencilerin düşünme şekillerinde ortaya çıkan alt kategorilere ait frekanslar

\begin{tabular}{llcccccc}
\hline Kategoriler & Alt Kategoriler & \multicolumn{7}{c}{ Frekans } \\
\hline & & $1 . \mathrm{a}$ & $1 . \mathrm{b}$. & $2 . \mathrm{a}$ & $2 . \mathrm{b}$ & $3 . \mathrm{a}$ & $3 . \mathrm{b}$ \\
Öğrencilerin & Artış miktarını örüntünün genel & 6 & 30 & 36 & 31 & 9 & 0 \\
$\begin{array}{l}\text { Düşünme } \\
\text { Şekilleri }\end{array}$ & $\begin{array}{l}\text { terimi olarak ifade etme } \\
\text { Kuralı sözel ifadelerle sinırlama }\end{array}$ & 4 & 11 & 25 & 29 & 3 & 1 \\
& $\begin{array}{l}\text { Takip eden terimi örüntünün } \\
\text { genel terimi kabul etme }\end{array}$ & 21 & 33 & 11 & 9 & 0 & 0 \\
& & & & & & \\
\hline
\end{tabular}

Frekanslar incelendiğinde öğrencilerin düşünme şekillerinin aritmetik genellemeye ulaştırma yönünde olduğu görülmektedir. Özellikle şekil örüntülerinde cebirsel genelleme yapmaya engel olan temel düşünme şeklinin artış miktarını örüntünün genel terimi olarak ifade etme olduğu görülmüştür. Öğrenciler ardışık terimler arası farka yoğunlaşmakta, bu da cebirsel genellemeye ulaşmalarına engel olmaktadır. $\mathrm{Bu}$ düşünceye sahip $\mathrm{O}_{27}$, "her şekle 4 tane kare eklenmiş. Bu nedenle genel terim $4 n$ 'dir." yanıtını vermiştir. ${ }_{35}$ ise "bu örüntünün genel terimi 4n'dir. Çünkü 4'er 4'er artıyor." ş̧eklinde yanıtlamıştır.

Şekil örüntülerinde karşımıza sıklıkla çıkan bir diğer düşünme şekli kuralı sözel ifadelerle sınırlandırmadır. Şekil örüntülerinde öğrencilerin büyük çoğunluğu aritmetik genellemenin göstergesi olan bu düşünme şeklini benimsemiştir. Örneğin $\ddot{O}_{37}$, "kural=3'er 3'er artmıştır." ifadesini kullanmıştır. $\mathrm{O}_{42}$ ise "birincide üç, ikincide altt, üncüde dokuz, dördüncüde on iki, n. de bir öncekinin 3 fazlası" şeklinde açıklama yapmıştır.

Takip eden terimi örüntünün genel terimi kabul etme en sık sayı örüntülerinde karşımıza çıkmıştır. $\ddot{O}_{38}$ "sayılar gittikçe +5 artıyorsa kural 28 olur" diyerek sıradaki verilemeyen terimi örüntünün genel terimi olarak belirtmiştir. Benzer şekilde $\mathrm{O}_{43}$ " 5 ' er 5 'er ritim şeklinde gidiyor. 8'e 5 ekledim 13 çıktı, 13'e 5 ekledim 18 çıktı, 18'e 5 ekledim 
23 çıtı ve kuralı buldum: 23 'e 5 ekledim 28 çıktı." Diyerek takip eden terimi genel terim olarak düşünmüştür.

Öğrencilerin aritmetik genellemeye ulaştıran düşünme şekilleri nedeniyle cebirsel genelleme yapamadıkları görülmüştür. Aritmetik genellemeye ulaştıran düşünme şekilleri ise özellikle şekil örüntüleri gibi kendilerini zorlayan bir temsil biçimi söz konusu olduğunda kendini göstermektedir. Benzer durum sayı örüntüleri için de geçerlidir. Sayı ve şekil örüntülerindeki bu benzerliğin nedeni, öğrencilerin şekil örüntüsünü sayı örüntüsüne dönüştürerek genel terimi bulmaya çalışmalarıdır. Bu yaklaşımları sonucunda iki temsil biçimi arasında hiçbir fark kalmamaktadır. Tablonun kullanıldığ belirgin olarak ortaya çıkan bir düşüncenin olmadığı görülmektedir. Bunun nedeni öğrencilerin bu soruya yanıt verme frekanslarının azlığıdır.

\subsection{Farklı Temsillerin Kullanımı}

$\mathrm{Bu}$ bölümde araştırmanın üçüncü alt problemi olan "ortaokul öğrencileri genelleme yaparken farklı temsil biçimlerini nasıl kullanmaktadır?" sorusu ele alınmaktadır. Öğrencilerin örüntülerin genel terimini bulmaya çalışırken temsilleri nasıl kullandıkları incelendiğinde şekil örüntüsünü sayı örüntüsüne dönüştürme, sayı örüntüsünü tabloya dönüştürme ve sayı örüntüsünü şekil örüntüsüne dönüştürme yaklaşımlarını izledikleri görülmüştür. Öğrencilerin bu üç yaklaşıma örnek olabilecek cevapları Tablo 8'de sunulmaktadır.

Tablo 8. Öğrencilerin temsil kullanma şekillerine örnek cevaplar

$\begin{array}{lll}\text { Temsil Öğrenci } & \text { Örnek Cevaplar } \\ \text { Kullanımları } & \end{array}$

Şekil örüntüsünü sayı örüntüsüne dönüştürme

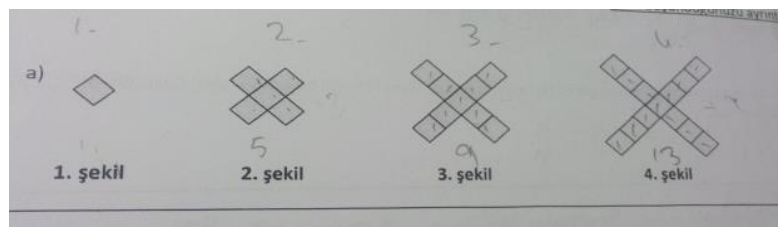

Sayı örüntüsünü tabloya dönüştürme

$\ddot{\mathrm{O}}_{10}$

$\begin{array}{lll}\text { 1. şekil şekil şekil } & \text { 2. }\end{array}$


Tablo 8'in devamı

Sayı örüntüsünü şekil örüntüsüne dönüştürme

$\ddot{\mathrm{O}}_{7}$

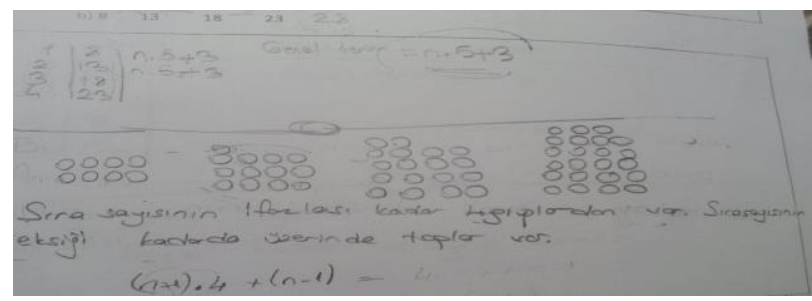

Ö$_{10}$ şekil örüntüsünde yer alan modeli yalnızca sayıları elde etmesini sağlayan bir araç olarak görerek şekil örüntüsünü sayı örüntüsüne dönüştürme yoluyla genellemeye çalışmıştır. $\mathrm{O}_{2}$ 'nin cevabı incelendiğinde basit bir tablo oluşturarak adım sırası ve terim arasında bir ilişki kurmayı amaçladığı görülmektedir. Ö${ }_{7}^{\prime}$ nin verilen örüntünün genel terimini hem tablo kullanarak hem de şekil örüntüsüne dönüştürerek açıkladığı görülmektedir. Öğrencilerin cevapları ile örneklendirilen çoklu temsillerin kullanımına ilişkin frekanslar Tablo 9'da verilmektedir.

Tablo 9. Temsil kullanımlarında ortaya çıkan alt kategoriler

\begin{tabular}{|c|c|c|c|c|c|c|c|}
\hline Kategoriler & Alt Kategoriler & & & Frek & slar & & \\
\hline & & $1 . \mathrm{a}$ & 1.b & $2 . a$ & 2.b & $3 . a$ & 3.b \\
\hline Temsil & $\begin{array}{l}\text { Şekil örüntüsünü sayı örüntüsüne } \\
\text { dönüstürme }\end{array}$ & - & - & 33 & 32 & - & - \\
\hline kullanımları & $\begin{array}{l}\text { Sayı örüntüsünü tabloya } \\
\text { dönüştürme }\end{array}$ & 30 & 16 & - & - & - & - \\
\hline & $\begin{array}{l}\text { Say1 örüntüsünü şekil örüntüsüne } \\
\text { dönüştürme }\end{array}$ & 0 & 3 & - & - & - & - \\
\hline
\end{tabular}

Temsil biçimlerini birbirlerine dönüştürme ve genel terimi bulmada ilk iki sorudan veri elde edilmiştir. Tablo ile sunulan örüntülerin bulunduğu üçüncü soruda başka bir temsil kullanımına geçilmemiştir.

Birinci soruda karşılaşılan iki yaklaşımdan biri sayı örüntüsünü tabloya dönüştürme diğeri ise sayı örüntüsünü şekil örüntüsüne dönüştürmedir. Öğrencilerin büyük bir kısmı say1 örüntüsünü tabloya dönüştürerek genelleme yapmaya çalışmışlardır. $\mathrm{Bu}$ öğrencilerden $\ddot{O}_{4}$ ve $\mathrm{O}_{40}$ birinci sorunun a seçeneğine aşağıdaki yanıtı vermişlerdir:

$\begin{array}{ll}1 & 1 \\ 2 & 2 \\ 3 & 3 \\ 4 & 4 \text { ise } \\ n & \text { n'dir. }\end{array}$


Birinci soruda öğrencilerden bazılarının sayı örüntüsünü tabloya dönüştürdüğü halde tablodaki iki sütun arasında ilişki kurma yerine ardışık terimler arasında ilişki kurmaya çalıştıkları gözlemlenmiştir. Bunlardan biri olan $\mathrm{Ö}_{48} \mathrm{~b}$ seçeneğini şöyle yanıtlamıştır:

$\begin{array}{rr}1 & 8 \\ 2 & 13 \\ 3 & 18 \\ 4 & 23 \\ n & n+5\end{array}$

olmalıdır. Çünkü 5'er 5'er artıyor.

Benzer şekilde aynı soruya $\ddot{O}_{5}$ :

$\begin{array}{rr}1 & 8 \\ 2 & 13 \\ 3 & 18 \\ 4 & 23 \\ 5 & 28\end{array}$

yanıtını vermiştir.

Birinci soruda karşılaşılan ikinci yaklaşım sayı örüntüsünü şekil örüntüsüne dönüştürmedir. $\mathrm{Bu}$ yaklaşım her ne kadar az sayıda öğrenci tarafından sadece $\mathrm{b}$ seçeneğinde kullanılmış olsa da (3 öğrenci) sonucu farklı ve yaratıcı bir yolla bulmuş olmaları nedeniyle rapor etmeye değer görmekteyiz. Bu yaklaşımı kullanan öğrencilerden Ö$_{6}$ soruyu aşağıdaki şekil örüntüsünü çizerek cevaplamıştır:
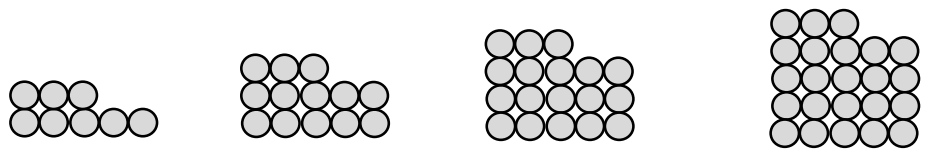

Adım sayısıyla 5 'i çarptım 3 ekledim. $5 n+3$. Şekillerle daha iyi anlıyorum.

Aynı yaklaşımı kullanan $\mathrm{O}_{3}$ ise aşağıdaki şekil örüntüsünü oluşturmuştur:
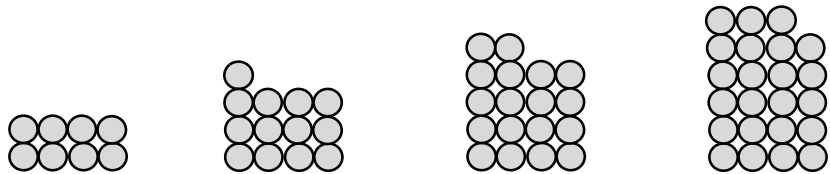

Stra sayının 1 fazlası kadar gruplar vardır. Sira saylsının 1 eksiği kadar üstünde toplar vardir. $(n+1) \cdot 4+(n-1)$ bulunur. 
$\mathrm{Bu}$ iki öğrencinin yanıtı farklı temsil kullanımının genelleme yapmadaki katkısını göstermektedir. Şekil örüntüsünün etkili olarak kullanılamadığı ikinci soruda öğrenciler, burada örneklendirilenin aksine şekillerin arasındaki ilişkilere odaklanmaktansa şekilleri sayarak sayı örüntüsüne geçiş yaptıkları görülmüştür. Bu yaklaşımı benimseyen öğrenciler ikinci sorunun a seçeneğini aşağıda örnek olarak yanıtı verilen $\ddot{O}_{37}$ gibi yanıtlamıştır:

$$
\begin{array}{ccccc}
1 & 5 & 9 & 13 & 17 \\
\text { 1. şekil } & \text { 2. şekil } & \text { 3. şekil } & \text { 4. şekil } & \text { 5. Şekil }
\end{array}
$$

Kuralı 4'er 4'er artmıştır.

Özetle en sık kullanılan stratejinin şekil örüntüsünü sayı örüntüsüne dönüştürme olduğu görülmüştür. Bu sonuç, giriş bölümünde örneklendirildiği gibi, öğrencilerin şekil örüntüsünden etkili şekilde yararlanamadıklarını göstermektedir. Öğrenciler zaman zaman sayı örüntüsünü tabloya dönüştürmüşler ancak genelleme yapma şekilleri incelendiğinde aritmetik genelleme eğilimlerinin dönüşüme rağmen devam ettiği belirlenmiştir. Şekil örüntüsü içeren sorularda ise genellikle öğrencilerin şekillerin arasındaki ilişkilere odaklanmaktansa şekilleri sayarak sayı örüntüsüne geçiş yaptıkları görülmüştür.

\section{Tartışma ve Sonuç}

$\mathrm{Bu}$ araştırmada ortaokul öğrencilerinin (i) farklı temsil biçimleriyle sunulan örüntüleri genellemede hangi genelleme türünü kullandıkları (ii) cebirsel genelleme yapmaya engel olan düşünme şekilleri ve (iii) genelleme yaparken farklı temsil biçimlerini nasıl kullandıkları incelenmiştir.

Araştırma bulguları öğrencilerin özellikle sayı ve şekil örüntülerinde cebirsel olarak genel kuralı ifade etmekte sıkıntı çektiklerini göstermektedir. Öğrenciler cebirsel genelleme yerine genel terimin yapısını açıklamaya çalışan aritmetik genellemeler yapmışlardır. Benzer sonuca Rico (1996) da ulaşmıştır. Rico araştırması sonucunda ögrencilerin aritmetik genelleme yapabildiklerini ancak cebirsel genelleme yapamadıklarını ifade etmiştir. Benzer şekilde MacGregor ve Stacey (1993) öğrencilerin tablo ile sunulan örüntülerde sergiledikleri yaklaşımları ve notasyon kullanımlarını incelemişlerdir. Araştırma sonucunda öğrencilerin tabloları devam ettirebildikleri ancak terim sırası ile terim arasındaki ilişkiyi incelemedikleri, terim sırası ile terim arasındaki ilişkiyi tanımlayabilseler bile kuralı cebirsel olarak yazamadıkları rapor edilmiştir.

Cebirsel genellemenin diğer örüntü temsillerine göre daha sık kendini gösterdiği temsil tablo temsilidir. Öğrenciler tablo olarak sunulan üçüncü soruda diğer sorulara göre daha fazla cebirsel genelleme yapmışlardır. $\mathrm{Bu}$ durumun nedeni üçüncü sorunun a seçeneğinde tablonun terim sayısı ile sırası arasındaki ilişkiye bakmaya yönlendiren şekilde hazırlanması olabilir. Tabloda çok sayıda ardışık terim sunulmadığından öğrenciler terim ile terim sırası arasındaki ilişkiye yönelmişlerdir. Göreceli olarak diğer sorulara göre daha fazla olsa da tablo ile sunulan örüntülerde de cebirsel genelleme yapma sıklığı yeterli düzeyde değildir.

Öğrencilerin cebirsel genelleme yapmalarına engel olan düşüncelerinden biri örüntü hangi temsil biçimiyle sunulursa sunulsun ardışı terimler arasındaki farka odaklanma ve 
terimler arası farkı genel terim olarak yazmadır. Carraher ve arkadaşları (2008) ve Stacey (1989) benzer sonuca ulaşmışlar ve ardışık terimler arasındaki farkın çarpılmasının öğrencilerin genelleme yaparken kullandıkları bir yöntem olduğunu belirtmişlerdir. Öğrencilerin sergilediği bir diğer düşünme şekli örüntüdeki ortaklığg sözel olarak ifade etme yönündedir. Benzer bulgu Yaman'ın (2010) araştırmasında elde edilmiştir. 317 öğrenciye on iki soruluk bir örüntü başarı testi uygulayan araştırmacı öğrencilerin örüntüye ait kuralı en çok sözel biçimde ifade ettiklerini belirtmiştir.

Araştırmaya katılan öğrenciler örüntüleri genellerken temsil biçimini etkili olarak kullanamamışlardır. Öğrenciler şekil örüntülerini önce sayı örüntüsüne dönüştürmüş daha sonra ardışık terimler arası ilişkiyi kullanmışlardır. Benzer durum tabloya dönüştürmede de kendini göstermektedir. Öğrencilerin tablodan yararlanma şekillerinin sayı örüntüsünden farklı olmadığı; her şekilde terimler arası artışa odaklandıkları görülmüştür. Benzer bulguya ulaşan Özdemir ve arkadaşları (2015) kendi araştırmalarındaki öğrencilerin verilen şekilleri veya şekillerin yapılarını dikkate almadıklarını ve örüntülerin kurallarını bulmak için sadece sayısal ilişkilere odaklandıklarını bulmuştur. Bu yaklaşımı benimseyen öğrenciler için farklı temsil biçimleriyle örüntüler sunmanın önemi kalmamaktadır. Öğrencilerin bu yönde ilerlemelerinin temel nedeni, verilen örüntüdeki ortaklığı görmelerini sağlayacak şekilde temsil biçiminden nasıl yararlanabileceklerini bilmemeleri olabilir. Diğer bir deyişle, öğrenciler cebirsel düşünme sürecinden geçerek genel terimi bulmakla sadece deneme yanılma yaparak veya terimler arasındaki ilişkiyi sözel olarak ifade ederek genel terimi bulma arasındaki farkı görememektedirler. $\mathrm{Bu}$ durum öğrencilerin bir şekilde genel terimi bulmalarını sağlayacak şekilde bir yaklaşım benimsemelerine ve farklı temsillerin genelleme yapmalarına sağlayacağı katkıyı fark etmemelerine neden olmaktadır. Özellikle şekil örüntülerinin ve tablonun etkili kullanımı, öğrencilerin cebirsel genelleme yapmalarına yardımcı olabilecek araçlardır. Şekil örüntüleri etkili kullanıldığında, daha açık bir ifadeyle şekillerin yapısındaki ortaklığı belirleyerek bunun üzerinden genelleme yapmayı sağlama yönünde kullanıldığında cebirsel düşünmenin gelişimine hizmet edebilir. Bu duruma vurgu yapan Ferrara ve Ferrari (2017) üç öğrenciyle gerçekleştirdiği araştırmasının sonucunda şekil örüntülerinin sadece uzamsal olarak şekillerin nasıl yerleştiğini fark etmenin yanı sıra her terim ile bu terimin şekil örüntüsündeki yeri arasında ilişki aramasını gerektirdiğini, bu yönüyle erken cebirsel düşüncenin gelişimine zemin oluşturduğunu belirtmiştir. Örneğin bu araştırmada iki öğrenci aynı şekil örüntüsüne ait genel kuralı şekillerdeki ortaklığı doğru belirleyerek $5 n+3$ ve $(n+1) .4+(n-1)$ şeklinde yazmayı başarmışlardır. Bu bağlamda temsil biçimlerinin etkili şekilde kullanılmasının önemli olduğunu düşünmekteyiz.

\section{5. Öneriler}

Araştırma sonuçları dikkate alındığında öğrencilerin temsil biçimine bağlı olmaksızın cebirsel genelleme yerine aritmetik genelleme yapmayı tercih ettiği görülmüştür. Öğrencilerin cebirsel genelleme yapmalarında önemli adımlardan biri örüntünün elemanları arasındaki ortaklığı yakalayabilmeleridir. Ancak öğrenciler söz konusu 
ortaklığı bizim istediğimizden farklı şekilde görebilmektedir (Hill, Lannin \& van Garderen, 2015). Bu bağlamda öğrencileri tanımak ve bu araştırmada da belirli yönlerden ele alınan genellemeleri yaparken benimsedikleri yaygın düşünme şekillerini bilmek öğrencilerin genelleme yapmalarını kolaylaştırabilir.

Caspi ve Sfard (2012) genelleme yapma sürecinde sayılar arasındaki ilişkilerin dikkatlice incelenmesiyle cebirsel düşünmenin gerçekleşebileceğini belirtmektedir. Örüntülerin farklı temsil biçimleri ilişkilerin incelenmesinde bir araçtır. Bu bağlamda şekil örüntülerinin genel kuralı bulma yönünde nasıl etkili kullanılabileceğine derslerde yer vermek hem genelleme yapmayı anlamlandırmada hem de aynı örüntüyü temsil eden birbirine eşit farklı cebirsel gösterimlerin olabileceğini fark etmelerini sağlamada etkili olabilir.

Araştırmamızda farklı şekillerde kullanılan temsil biçiminden bağımsız olarak öğrencilerin ardışı terimler arası ilişkiye odaklanma, kuralı sözlü olarak ifade etme gibi aritmetik geneleme yapma yönündeki düşünme biçimlerinin cebirsel genelleme yapmalarına engel olduğu sonucuna ulaşılmıştır. 12-13 yaş grubundaki öğrencilerin çoklu temsillerle genelleme yapma becerilerini inceleyen Wilkie (2016) örüntü genelleme becerisinin seviyesinin esnek ve orantısal düşünme becerileri ile ilişkili olduğu sonucuna ulaşmıştır. Bu iki araştırma bulgusundan hareketle yeni araştırma önerisi olarak farklı temsil biçimlerinden yararlanarak genelleme yapmada düşünme şekillerinin rolü incelenebilir.

$\mathrm{Bu}$ araştırmada faklı temsil biçimleri ile sunulan örüntülerin genellenmesi süreci betimsel olarak incelenmiştir. Genelleme sürecinin doğası dikkate alınarak tasarlanan uzun süreli araştırmalar gerçekleştirilerek etkinliklerin cebirsel düşüncenin gelişiminin gözlemlenmesi tasarlanabilecek araştırmalardan biri olabilir. Böyle bir araştırma sonucunda gerek öğretim programlarına gerekse de ders kitaplarında genelleme ve örüntü kavramlarının daha etkili olarak ele alınmasını sağlayacak bulgulara ulaşılabilir. 


\section{Middle School Students' Mathematical Generalization Abilities with the use of Different Representations}

\section{Extended Abstract}

School mathematics, in essence, contains algebra (Otte, Mendoza, Gonzaga \& de-Barros, 2015). Beyond being a language in which algebraic letters are used, anticipation emerges as a way of thinking and involves algebraic thinking which requires analyzing, interpreting, verifying, problem solving, predicting, and generalization of values (Kieran, 1996). Research on the development of algebraic thinking seems to focus particularly on generalizations and patterns (eg., Moss \& Beatty, 2010; Rivera, 2011; Ferrara \& Sinclair, 2016). This is because the relationship between students' ability to understand and generalize patterns (Warren, 2000) or, more clearly, pattern searching is one of the basic and necessary steps to generalize (Jones, 1993).

In addition to the explanations on generalization, the demand for review as a followable and observable process has led to the formation of theoretical frameworks (eg., Radford, 2008; Rivera, 2011). In the next sub-section, "architecture of algebraic pattern generalization" (Radford, 2008), which is adopted as the theoretical framework of this research, is explained because it enables to follow the generalization process operationally and to determine generalization types.

\section{Theoretical Framework}

This study investigates middle school students' generalization processes. Radford's (2008) framework, the architecture of algebraic pattern generalization, is embraced as the theoretical framework for this study since this framework can serve as an analytical tool for investigating experimental and theoretical generalization.

According to Radford (2008) finding an algebraic expression for a pattern should end up with an algebraic generalization. The process of generalizing patterns includes the following phases:

i. Grasping a commonality in a number pattern,

ii. Extending or generalizing this commonality to all subsequent terms,

iii. Using the commonality to provide a direct expression of any term of the pattern

Figure 1 below explain these phases:

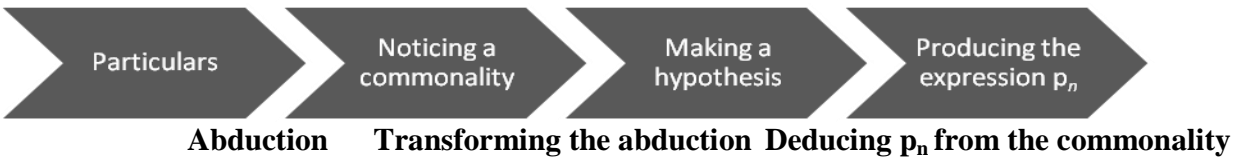

Figure 1. The architecture of algebraic pattern generalisation (Radford, 2008: 85) 
On the other hand, arithmetic generalization focuses on only a particular part of the pattern, therefore generalization which produces any term of the pattern is not possible. In arithmetic generalization, the last phase in Figure 1 does not exist. Naïve induction does not include the first and last phase of an algebraic generalization and does not consider the relationship between the terms of the pattern. It is purely based on trial and error method by just guessing the formula.

\section{The purpose of the study}

In this research, it is aimed to examine the forms of thinking and generalization types of students in the generalization of the patterns presented with different forms of representations. Students are asked to examine the patterns of generalizations presented in different forms of representations in the context of the theoretical framework, to determine the forms of thinking that lead to the emergence of different generalization models, to determine the forms of thinking that prevent them from doing algebraic generalizations and to determine the ways in which students use different forms of representation. Following research questions are formulated considering this aim:

-What kinds of generalization types do middle school students use to generalize patterns which are given in different representational forms?

- What are the forms of middle school students' thinking that hinder algebraic generalization?

-How do middle school students use different representational forms when generalizing number patterns?

\section{Methodology}

Case survey method was used for the study. This model was embraced because of its potential to reveal generalization processes used by students to find algebraic formulas for patterns that were given in different representations. Participants of the study were selected based on purposeful sampling. Ninety-two middle school students (from sixth, seventh and eighth grade) in schools in İzmir voluntarily participated in the study. They were asked six questions which required finding the algebraic rule for the patterns in different representational forms such as table and pictorial models. Their answers were analyzed using descriptive and content analysis.

\section{Results}

Results are presented in three sections. First, in terms of generalization types, results indicated that students tended to use arithmetic generalization and naïve induction instead of algebraic generalization. One exception was a pattern which was presented in a table which directs students to focus on the relationship between term number and the corresponding term. Second, in terms of students' types of thinking which prevents algebraic thinking, students had difficulties with finding an algebraic formula when the patterns were presented pictorially. In this case, they used arithmetic generalization. Third, 
in terms of using different representations, the most important finding is concerned with students' strategies to find the algebraic formula. They transformed pictorial patterns into table form. This indicated that they did not make use of pictorial representation in an effective way. Another finding is that students represented number patterns in the form of a table. However, they could not make use of tables to make generalizations. Instead, they continued to use arithmetic generalization. When patterns were presented pictorially, they tend to count the parts in the picture and obtain a number pattern instead of focusing on the relationship in the pictorial pattern.

\section{Conclusion and Discussion}

In this study, it was investigated how secondary school students (i) used the different patterns of representation in the generalization; (ii) the forms of thinking that prevented them from making algebraic generalization, and (iii) used different forms of representation in generalization.

The findings showed that students especially have difficulties in expressing the general rule in algebraic numbers and figure patterns. The students made arithmetic generalizations trying to explain the structure of the general term rather than algebraic generalization. A similar result has been reached by Rico (1996). As a result of the Rico's (1996) research, students stated that they could make arithmetic generalizations but not algebraic generalizations. Similarly, MacGregor and Stacey (1993) investigated the use of notation and the approaches presented in the table with 143 students. As a result of the research, it is reported that the students can continue the tabulation, but they cannot write the relation between the term order and the term, nor can they write the order algebraically even if they can define the relation between the term order and the term.

Algebraic generalization is represented by table which is more frequently seen than other pattern representations. In the third question the students made more algebraic generalizations than the other questions. This may be due to the fact that in the third question, the tabulation may be tailored to look at the relationship between the number of terms and the rank. Since there are not many consecutive terms presented in the table, the students are directed to the relation between the term and the term order. The frequency of algebraic generalizations is not sufficient for the patterns presented in the table although frequencies were relatively higher for other questions.

One of the considerations that prevented students from doing algebraic generalizations is to focus on the difference between consecutive terms. Carraher, Martinez and Schliemann (2008) and Stacey (1989) reached a similar result and stated that multiplication of consecutive terms is a method used by the students in generalization. Another way of thinking that students exhibit is to express the relationship in the pattern verbally. Similar findings were obtained in Yaman's (2010) research. 317 students who performed a pattern achievement test of the twelve questions expressed the pattern verbally. 
The students participating in this research were not able to use different forms of representations effectively when the patterns were generalized. The students transformed the pictorial patterns into number patterns and then used the relation between consecutive terms. The similar situation also manifests itself in transforming into a table. The way that the students use the table is not different from the number pattern; it has been seen that they focus on the increase in terms anyway. Özdemir, Dikici and Kültür (2015), who have reached similar findings, found that students in their research did not take into consideration the forms of the given patterns and focused only on numerical relations in order to find the rules of the patterns. Students do not see the difference between finding a general term through the process of algebraic thinking and finding general term by simply making a trialerror method and expressing the relation between terms verbally. This leads students to adopt an approach that somehow finds a general rule and does not recognize the contribution that different representations will make to generalization.

\section{Kaynaklar/References}

Carraher, D. W., Martinez, M., \& Schliemann, A. D. (2008). Early algebra and mathematical generalization. The International Journal on Mathematics Education, 40(1), 3-22.

Caspi, S., \& Sfard, A. (2012). Spontaneous meta-arithmetic as a first step toward school algebra. International Journal of Educational Research, 51-52, 45-65.

Davydov, V. V. (1990). Soviet studies in mathematics education, volume 2. types of generalization in instruction: logical and psychological problems in the structuring of school curricula. Reston Virginia: National Council of Teachers of Mathematics.

Dörfler, W. (1991). Forms and means of generalization in mathematics. In A. J. Bishop (Ed.), Mathematical knowledge: Its growth through teaching (pp. 63-85). Dordrecht: Kluwer Academic Publishers.

Ferrara, F., \& Sinclair, N. (2016). An early algebra approach to pattern generalisation: Actualising the virtual through words, gestures and toilet paper. Educational Studies in Mathematics, 92(1), 1-19.

Ferrara, F., \& Ferrari, G. (2017). Agency and assemblage in pattern generalisation: A materialist approach to learning. Educ Stud Math, 94(1), 21-36.

Jones, L. (1993). Algebra in the primary school. Education, 21(2), 27-31.

Frobisher, L., \& Threlfall, J. (1999). Teaching and assessing patterns in the primary years. In A. Orton (Ed.), Pattern in the teaching and learning of mathematics (pp. 64-103). London: Cassell.

Harel, G., \& Tall, D. (1991). The general, the abstract and the generic in advanced mathematics. For the Learning of Mathematics, 11(1), 38-42.

Hill, T., Lannin, J., \& van-Garderen, D. (2015). Promoting and assessing mathematical generalising. Australian Primary Mathematics Classroom, 20(4), 3-8.

Kaput, J. (1999). Teaching and learning a new algebra. In T. Romberg \& E. Fennema (Eds.), Mathematics classrooms that promote understanding (pp. 133-155). Hillsdale, NJ: Lawrence Erlbaum. 
Kılıç, Ç. (2016). Ortaokul öğrencilerinin lineer sayı örüntüsüne bağlı olarak şekil örüntüsü oluşturma stratejilerinin analizi. Eğitimde Kuram ve Uygulama, 12(6), 1205-1230.

Kieran, C. (1996). The changing face of school algebra. In C. Alsina, J. Alvarez, B. Hodgson, C. Laborde \& A. Pérez (Eds.), 8th international congress on mathematical education: Selected lectures (pp. 271-290). Seville, Spain: S.A.E.M. Thales.

Krutetskii, V. A. (1976). The psychology of mathematical abilities in schoolchildren. Chicago: The University of Chicago Press.

Lannin, J., Ellis, A., Elliott, R., \& Zbiek, R. (2011). Developing essential understanding of mathematical reasoning for teaching mathematics in grades pre- $K-8$. Reston: NCTM.

Mason, J. (1996). Expressing generality and roots of algebra. In N. Bednarz, C. Kieran, \& L. Lee (Eds.), Approaches to algebra: Perspectives for research and teaching (pp. 6586). Dordrecht, The Netherlands: Kluwer Academic.

MacGregor, M., \& Stacey, K. (1993). Seeing a pattern and writing a rule. In Hirabayashi, N. Nohda, K. Shigematsu and F. Lin (Eds.), Proceeding of The 17th Conference for Psychology of Mathematics Education (Vol I, pp. 181-188). Tsukuba, Japan.

Moss, J., \& Beatty, R. (2010). Knowledge building and mathematics: Shifting the responsibility for knowledge advancement and engagement. Canadian Journal of Learning and Technology, 36(1), 22-54.

Otte, M. F., Mendonça, T. M., Gonzaga, L., \& de Barros, L. (2015). Generalizing is necessary or even unavoidable. PNA, 9(3), 143-164.

Özdemir, E., Dikici, R. ve Kültür, M. N. (2015). Öğrencilerin örüntüleri genelleme süreçleri: 7. Sınıf örneği. K. Ü. Kastamonu Ĕ̆itim Dergisi, 23(2), 523-548.

Radford, L. (2008). Iconicity and contraction: A Semiotic investigation of forms of algebraic generalizations of patters in different contexts. ZDM Mathematics Education, 40, 83-96.

Radford, L. (2010). Elementary forms of algebraic thinking in young students. In M. F. Pinto \& T. F. Kawasaki (Eds.), Proceedings of the 34th conference of the international group for the psychology of mathematics education (Vol. IV, pp. 73-80). Belo Horizonte: PME.

Rico, L. (1996). The role of representation systems in the learning of numerical structures. In L. Puig, \& A. Gutierrez (Eds.), Proceedings of the 20th Conference of the International Group for the Psychology of Mathematics Education (Vol. I, pp. 87-102). Valencia: University of Valencia.

Rivera, F. D. (2011). Toward a visually-oriented school mathematics curriculum. New York: Springer.

Rubinshtein, S. L. (1994). Thinking and ways of investigating it. Journal of Russian and East European Psychology, 32(5), 63-93.

Stacey, K. (1989). Finding and using patterns in linear generalising problems. Educational Studies in Mathematics, 20, 147-164.

Tanışlı, D. ve Özdaş, A. (2009). İlköğretim beşinci sınıf öğrencilerinin örüntüleri genellemede kullandıkları stratejiler. Kuram ve Uygulamada Ĕ̆itim Bilimleri, 9(3), 1453-1497. 
Tanışl1, D. ve Yavuzsoy-Köse, N. (2011). Lineer şekil örüntülerine ilişkin genelleme stratejileri: Görsel ve sayısal ipuçlarının etkisi. Eğitim ve Bilim, 36(160), 184-198.

Venenciano, L., \& Heck, R. (2016). Proposing and testing a model to explain traits of algebra preparedness. Educational Studies Mathematics, 92, 21-35.

Warren, E. (2000). Visualisation and the development of early understanding in algebra. In T. Nakahara \& M. Koyama (Eds.), Proceedings of the 24th conference of the International Group for the Psychology of Mathematics Education (Vol. IV, pp. 273280). Hiroshima, Japan.

Wilkie, K. J. (2016). Students' use of variables and multiple representations in generalizing functional relationships prior to secondary school. Educational Studies in Mathematics, 93, 333-361.

Yakut-Çakır, M. Ve Akyüz, G. (2015). 9. sınıf öğrencilerinin örüntü genelleme problemlerini çözme stratejilerinin belirlenmesi. Necatibey Ĕgitim Fakültesi Elektronik Fen ve Matematik Ĕ̈itimi Dergisi, 9(2), 205-229.

Yaman, H. (2010). Illköğretim ögrrencilerinin matematiksel örüntülerdeki ilişkileri algılayışları üzerine bir inceleme (Doktora tezi). Hacettepe Üniversitesi, Sosyal Bilimler Enstitüsü, Ankara.

Yıldırım, A. ve Şimşek, H. (2013). Sosyal bilimlerde nitel araştırma yöntemleri. Ankara: Seçkin Yayıncılık.

Yılmaz, R. ve Argün, Z. (2013). Matematiksel genelleme sürecinde görselleştirme ve önemi. Hacettepe Üniversitesi Eğitim Fakültesi Dergisi, 28(2), 564-576.

\section{Kaynak Gösterme}

Yeşildere-İmre, S., Akkoç, H. ve Baştürk-Şahin, B. N. (2017). Ortaokul öğrencilerinin farklı temsil biçimlerini kullanarak matematiksel genelleme yapma becerileri. Türk Bilgisayar ve Matematik Eğitimi Dergisi, 8(1), 103129.

\section{Citation Information}

Yeşildere-İmre, S., Akkoç, H., \& Baştürk-Şahin, B. N. (2017). Middle school students' mathematical generalization abilities with the use of different representations. Turkish Journal of Computer and Mathematics Education, 8(1), 103-129. 